\title{
The role of supply chain on the competitiveness and the performance of restaurants
}

\author{
Juliana Juliana $^{a^{*}}$, Rocky Nagoyaa, B.M.A.S. Anaconda Bangkara ${ }^{\mathrm{b}}$, John Tampil Purba ${ }^{\mathrm{a}}$ and Fachrurazi \\ Fachrurazi $^{*}$
}

${ }^{a}$ Universitas Pelita Harapan, Tangerang, Indonesia

${ }^{b}$ President University, Indonesia

${ }^{c}$ IAIN Pontianak, Indonesia

A B S T R A C T

Article history:

Received October 12, 2021

Received in revised format

October 26, 2021

Accepted December 142021

Available online

December 142021

Keywords:

Supply chain management

Competitiveness

Performance

Restaurant

\begin{abstract}
The purpose of this study is to analyze the effect of supply chain management on competitiveness, the positive effect of supply chain management on performance and the positive influence of competitiveness on performance in restaurants in the province of Banten Indonesia. The research method uses a hypothesis testing model, the respondents of this research are tourists who want to travel to a tourist attraction in Banten Province. Data collection is done online, using the Google Form website. Researchers distributed questionnaires to tourists using social media who had visited Banten province. This study uses a convenience sampling technique, where the sample members are respondents who are easy to find, and the convenience makes data collection more effective and efficient since it saves time and costs. The sample in this study was 290 tourists who had visited Banten Province. The technique of collecting data in this study used an online questionnaire, data analysis using structural equation modeling (SEM) by applying SmartPLS 3.0 software. Based on the results of data analysis, the results show there is a significant relationship between supply chain management and competitiveness, a significant relationship exists between supply chain management and restaurant performance and finally, competitiveness influences positively the restaurant performance.
\end{abstract}

\section{Introduction}

In the era of industrial revolution 4.0 and globalization, tourism as a commodity that is needed by almost every individual, by carrying out tourism activities can increase creativity, reduce the level of boredom at work, open insight into the culture of an area, relax, know the related heritage of a nation, and do business. According to Afum et al. (2021) tourism is very influential on state revenue through foreign exchange and taxes and increases the residents' incomes. The development of the tourism industry in Indonesia itself is supported by various tourism potentials. Very diverse tourism objects absorb many tourists both domestic and foreign to visit it. According to Ahmed et al. (2021), one of the supporting facilities needed by tourists when carrying out tourism activities is the service industry engaged in food and beverages or better known as restaurants. According to Affandi et al. (2020) and Pramono et al. (2021) restaurants as one of the important means in tourism activities are independent and some are integrated with the hotel environment. According to Alsmairat et al. (2022) the variety of restaurants that are growing and developing at this time and it is necessary to identify the classification of these restaurants and the dishes offered. The diversity of restaurants that develop in a tourist destination is a difficult choice for tourists to make purchases of products offered by various restaurants located in a destination. 
According to Alsmairat et al. (2022) and Asamoah et al. (2021), tourism is one sector that is very promising, especially for countries that have a diversity of cultures, traditions, and tourist objects. If properly managed, all of these can be a source of income and prosperity for the people who are directly related to the tourism activities as well as those who are affected indirectly. To advance tourism, facilities that can support it are needed, namely the hospitality industry. According to Rudyanto et al. (2021) and Juliana et al. (2021) the existence of the hospitality industry in an area becomes a very big attraction for tourists, both those whose purpose is to seek entertainment or for business purposes. Food and beverage facilities have a very important role to support the services provided by destinations to tourists, therefore they need to be managed professionally. Restaurants and bars are physical components of tourism, which function as one of the tourism facilities that greatly support services. According to research conducted by Saragih et al. (2020), Tovma et al. (2020), Wang et al. (2020) and Wieland et al. (2021), restaurants have a significant role in determining tourist destinations. According to Napitupulu et al. (2021) and Utama et al. (2021) as many as $20 \%$ of the tourists who visited a tourist area for the first time agreed that restaurants play a very important role in the selection of tourist destinations. Meanwhile, $46 \%$ of tourists who have had positive experiences at restaurants in these tourist destinations agree to return to visit at the next opportunity due to reasons to be able to enjoy service at the same restaurant again. This shows that the role of restaurants and bars is very important in the tourism industry. Business actors in this field need to know the standard quality of restaurant products desired by tourists to achieve tourist satisfaction.

According to Borazon et al. (2021), satisfaction is a person's feeling of pleasure or disappointment that arises after comparing the performance (results) of the product thought to the expected performance (results). If performance is below expectations, the customer is dissatisfied. If performance meets expectations, the customer is satisfied. If performance exceeds expectations, the customer is very satisfied or happy. In the world of hospitality, especially in the field of tourism, it is very important for companies to be able to achieve maximum tourist satisfaction because with maximum tourist satisfaction, it will be able to create repeat guests. One thing that can be done is to provide tourism products that are in accordance with the wishes and needs of tourists. According to Borazon et al. (2021) and Doan et al. (2020), customer satisfaction is an individual's perception of the performance of a product or service in relation to the customer's own expectations (expectations). According to Rudyanto et al. (2021) and Wijaya et al. (2021), everyone will have different expectations. The relationship between the level of customer satisfaction and customer behavior can be identified by several types of customers, namely: 1) apostles, namely customers whose product performance exceeds their expectations so that they can provide positive word of mouth information to others, or these customers are very satisfied customers who become loyal and continue to buy, 2) defectors are customers who are quite satisfied (neutral) and ready to stop buying, 3) terrorists are the type of consumers who have negative experiences, who can spread negative issues, 4) hostages are unhappy customers who still buying because of some conditions such as the low price. These customers are hard to talk to because they often make complaints, and 5) mercenaries are very satisfied customers who are not loyal, who might turn out to be defectors if they get cheap prices elsewhere.

According to Haudi et al. (2021) and Purwanto et al. (2021) supply chain management is a way that can make this competitiveness a success. If this theory is implemented properly, it will be able to further increase the company's competitiveness. Some researchers such as Borazon et al. (2021), Doan et al. (2020) and Herden et al. (2020) recognize the effectiveness of supply chain management in reducing costs. For this reason, it is necessary to ensure that supply chain management can make the company competitive, so it is necessary to study the factors that determine the success of supply chain management in terms of increasing the competitiveness of the company. Then these factors must be identified so that the company will really know the effectiveness. According to Jifroudi et al. (2020). performance is quantity and quality of work completed by individuals, groups or organizations. The performance aspect consists of three components, namely quality, quantity and effectiveness. Supply chain management is an effort to integrate the parties involved in the supply chain activities of making a product to improve operating efficiency, quality and service to customers.

Competitive advantage according to Saragih et al. (2020) and Tovma et al. (2020) is the ability of a company to achieve economic benefits above the profits that can be achieved by competitors in the same market. Companies that have competitive advantages always can understand changes in market structure and are able to choose effective marketing strategies. According to Yuliantoro et al. (2019) and Prahiawan et al. (2022) competitive advantage or competitive advantage is the ability of a company to achieve economic benefits above the profits that can be achieved by competitors in the same market. Performance or performance is often interpreted as the result of work or work performance. According to Chidir et al. (2021) and Muhajir et al. (2021), performance has a broader meaning, not only stating the results of work, but also how the work process takes place. Performance is about doing the job and the results achieved from that work. Performance is about what is done and how to do it. Performance is the result of work that has been compiled. Meanwhile, according to Saragih et al. (2020) and Tovma et al. (2020) performance is work ability shown by work results. According to Wang et al. (2020) and Wieland et al. (2021) performance is the work that can be achieved by a person or group of people in a company in accordance with their respective authorities and responsibilities to achieve company goals. The purpose of this study is to analyze the effect of supply chain management on competitiveness, the positive effect of supply chain management on performance and the positive influence of competitiveness on performance in restaurants in the province of Banten Indonesia. 


\section{Hypothesis Development}

\subsection{The relationship between supply chain management and restaurant competitiveness}

Previous research related to the relationship between supply chain management and restaurant competitiveness by Setiawan et al. (2021) there is a significant relationship between supply chain management and competitiveness, this result is in line with Sri et al. (2020) that there is a positive and significant relationship between supply chain management and competitiveness. Another study by Khaddam et al. (2020) and Ketchen et al. (2020) stated that supply chain management has a positive and significant effect on competitiveness. Based on the previous studies, the following hypothesis is proposed:

\section{H1: There is a positive relationship between supply chain management and restaurant competitiveness.}

\subsection{The relationship between supply chain management and restaurant performance}

Previous studies associated with the relationship between supply chain management and restaurant performance by Purwanto et al. (2021) that supply chain management has a positive and significant effect on performance, this result is in line with Setiawan et al. (2021) and Sri et al. (2020) that supply chain management has a positive and significant effect on performance. Another study by Khaddam et al. (2020) and Ketchen et al. (2020) states that supply chain management has a positive and significant effect on performance. Based on previous research, the following hypotheses were formulated:

\section{$\mathbf{H}_{2}$ : There is a positive relationship between supply chain management and restaurant competitiveness.}

\subsection{The relationship between competitiveness and restaurant performance}

Previous research studies related to the relationship between supply chain management and restaurant performance by Purwanto et al. (2021) state that competitiveness has a positive and significant effect on performance. Another study by Setiawan et al. (2021) and Khaddam et al. (2020) indicate that competitiveness has a positive and significant effect on performance, which is in line with Ketchen et al. (2020) that competitiveness has a positive and significant effect on performance. Therefore, the following hypothesis is proposed:

H3: There is a positive relationship between restaurant competitiveness and performance.

\section{Method}

The research method uses a hypothesis testing model and applies a cross sectional model, where data is collected completely within a certain time. The respondents of this research are tourists who want to travel to a tourist attraction in Banten Province. Data collection is performed online, using the Google Form website. Researchers distributed questionnaires to tourists using social media who had visited Banten province previously. The study uses a convenience sampling technique, where the sample members are respondents who are easy to find and the convenience makes data collection more effective and efficient since it saves time and costs. The sample in this study was 290 tourists who had visited Banten Province. The technique of collecting data in this study used an online questionnaire, data analysis is performed using structural equation modeling (SEM) using SmartPLS 3.0 software.

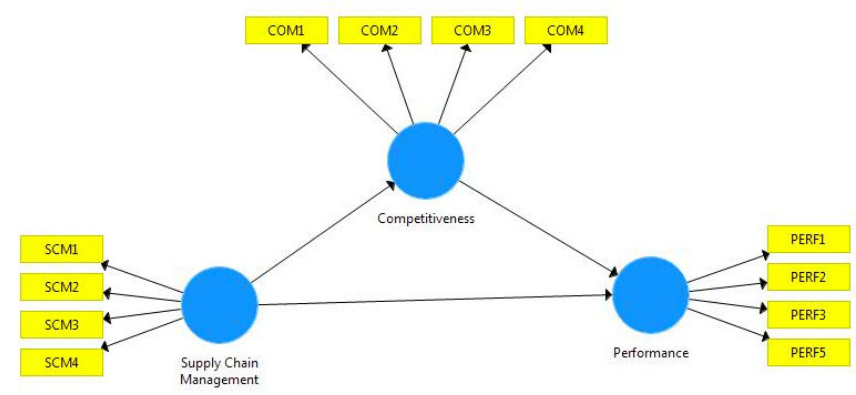

Fig. 1. Research Model

\section{Result and Discussion}

\subsection{Test Outer Model}

\subsubsection{Convergent Validity}

In testing the convergent validity, it is said to be valid if the value on the outer loading of each indicator is correlated more than 0.7 according to Purwanto et al. (2021). Fig. 2 shows the loading factor value of the model made through Smart-PLS 
3.0. The results show the value of each tested indicator has a value of $>0.7$ and it can be concluded that all indicators have valid results.

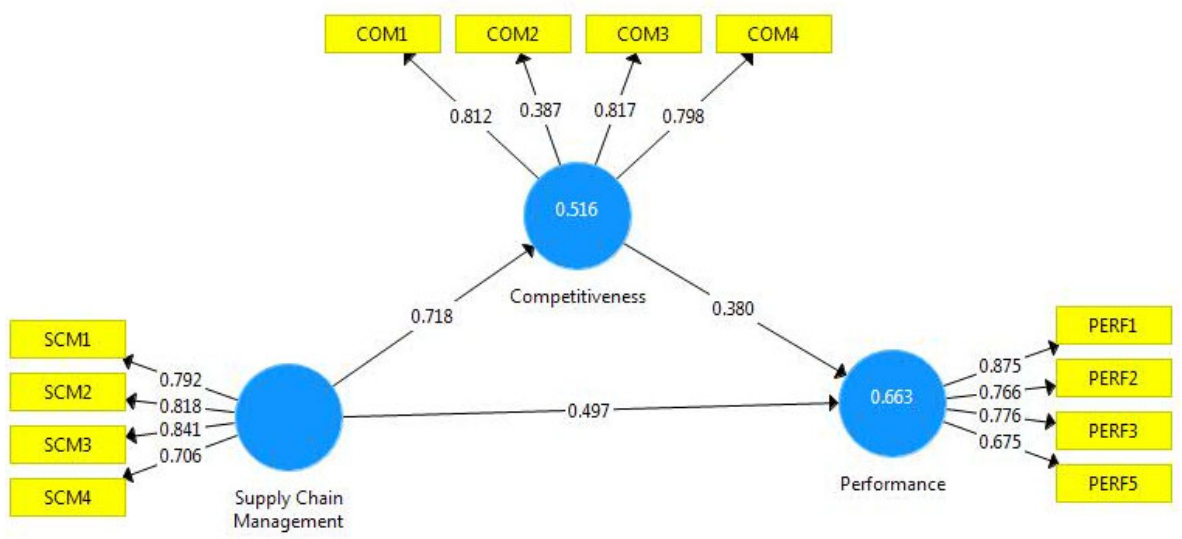

Fig. 2. Validity Testing

\subsubsection{Discriminant Validity}

Discriminant validity has been carried out to ensure that each concept of each latent variable is different from other latent variables. The discriminant validity of the measurement model with reflective indicators has been assessed based on the cross loading of measurements with variables (Purwanto et al., 2020). The model yields a good discriminant validity if the loading value of each latent variable indicator has the largest loading value compared with other loading values for other latent variables. From the results of the discriminant validity test, each latent construct indicator has the largest loading factor value when compared to other loading values so that the model has a good discriminant validity value, which is $>0.7$ for each variable (Purwanto, 2019).

\subsection{Reliability}

Reliability testing attempts to detect the size of a test that has consistent and stable results (Purwanto et al., 2021). The reliability of the measurement model gets good results if the value is more than the rule of thumbs alpha value or composite reliability $>0.6$ (Purwanto et al., 2021).

Table 1

Items Loadings, Cronbach's Alpha, Composite Reliability, and Average Variance Extracted (AVE)

\begin{tabular}{|c|c|c|c|c|}
\hline Variables & Cronbach's Alpha & Rho A & Composite Reliability & AVE \\
\hline Competitiveness & 0.695 & $0.7 \overline{7} 2$ & 0.808 & 0.528 \\
\hline Performance & 0.778 & 0.797 & 0.857 & 0.602 \\
\hline Supply Chain Management & 0.799 & 0.807 & 0.869 & 0.625 \\
\hline Competitiveness & 0.695 & 0.772 & 0.808 & 0.528 \\
\hline
\end{tabular}

\subsubsection{Inner model test}

Inner model test can be done in three ways. The three ways are by looking at R2, Q2 and GoF Inner Model Test (R-square). The coefficient of determination is used to determine the magnitude of the relationship between the independent variable and the dependent variable.

Table 2

The results of $R$ Square

\begin{tabular}{ccc}
\hline & R Square & R Square Adjusted \\
\hline Competitiveness & 0.516 & 0.511 \\
Performance & 0.663 & 0.657 \\
\hline
\end{tabular}

The results of R-Square for the first variable, competitiveness, is 0.516 , which means the dependent variable of competitiveness is influenced by the proposed model of supply chain management and the remaining value of $48.4 \%$ is described by other variables which are outside of the model. In addition, the value of R-Square is equal to 0.663 which means about $66 \%$ of the dependent variable of performance is influenced by the proposed model of supply chain management and competitiveness while the remaining is described by other variables which are outside the model. 


\subsubsection{Inner Model Predictive Relevance Test (Q2)}

Inner model predictive relevance (Q2) test was conducted to determine the relative effect of the structural model on the measurement of latent variable observations. The value in the predictive relevance (Q2) model is said to have predictive relevance if the results of Q2 $>0$ observation measurements have been reconstructed properly. The results of the calculation of Q2 show that the value of Q2 $>0$. That the model that has been made has predictive relevance.

\subsubsection{Goodness of Fit (GoF)}

The Goodness of Fit (GoF) inner model test is used to find the Goodness of Fit (GoF) value. The GoF value in PLS-SEM must be searched manually. Tenenhaus (2004) says that the inner goodness of fit test has three criteria, namely small (0.1), medium (0.25) and large (0.38). Goodness of Fit (GoF) test is conducted to determine the feasibility of a model. Based on the calculation, the GoF above can be concluded that the GoF value obtained is 0.57 including in the large category. So the model is declared fit.

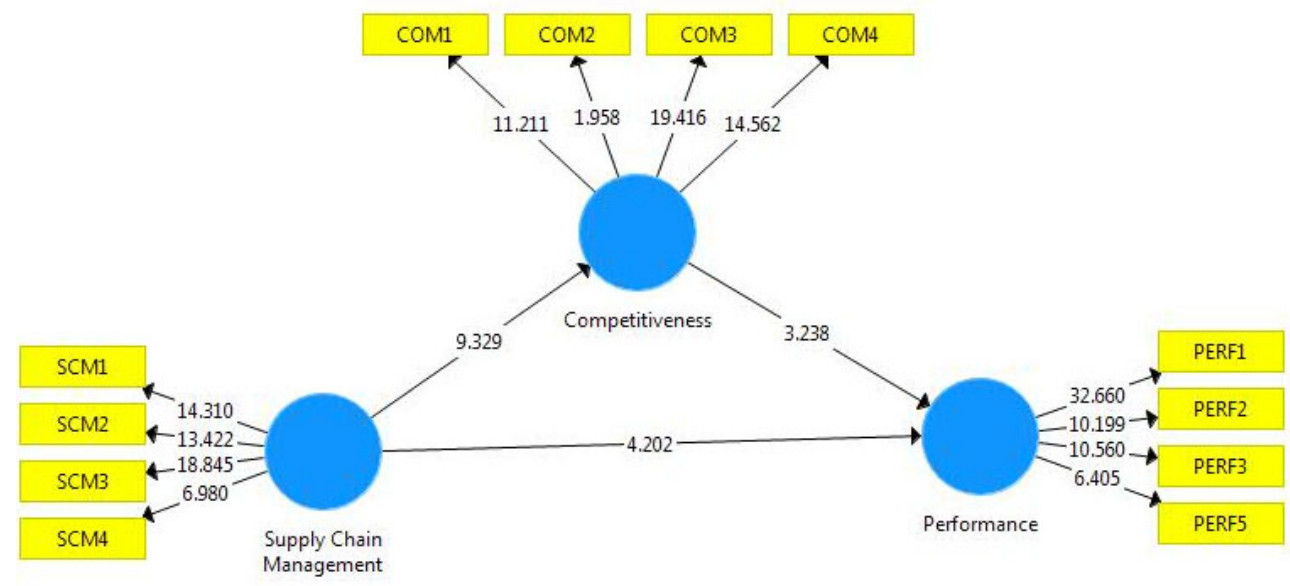

Fig. 3. Hypothesis Testing

\subsection{Hypothesis Testing}

Hypothesis testing or significance testing aims to evaluate the effect of the relationship between variables. Statistical testing of each hypothesized relationship was carried out using a bootstrapping simulation. Table 3 shows the results of the bootstrapping simulation. We see the overall composite reliability value for each variable is $>0.6$. Thus, it can be concluded that the measurement model of each variable has good reliability. As for the AVE value, each variable has a value of more than 0.5 so it can be concluded that the discriminant requirement is achieved. Average Variance Extracted (AVE) is the average percentage of a variance explained by items in a construct.

Table 3

Hypotheses Testing

\begin{tabular}{llll}
\hline Hypothesis & Relationship & P-Value & Decision \\
\hline $\mathrm{H}_{1}$ & Supply Chain Management $\rightarrow$ Competitiveness & 0.001 & Supported \\
$\mathrm{H}_{2}$ & Supply Chain Management $\rightarrow$ Performance & 0.002 & Supported \\
$\mathrm{H}_{3}$ & Competitiveness $\rightarrow$ Performance & 0.001 & Supported \\
\hline
\end{tabular}

The first hypothesis of the survey investigates the positive effect of supply chain management on competitiveness of restaurant industry. The result has indicated that supply chain management has maintained a strong positive effect of competitiveness $(\beta=9.329, \mathrm{P}$-value $=0.001)$. The result is in line with other previous studies (Purwanto et al., 2021). Other studies such as Setiawan et al. (2021), Sri et al. (2020), Khaddam et al. (2020) and Ketchen et al. (2020) also indicate that supply Chain Management has a positive and significant effect on Competitiveness.

The second hypothesis of the survey looks to find out whether supply chain management could possibly influence positively on performance or not. The result of our survey has indicated that supply chain management $(\beta=4.202, \mathrm{P}$-value $=0.002)$ has a positive effect on the performance of restaurant when the level of significance is five percent. The results are consistent with other findings as mentioned earlier (e.g. Setiawan et al., 2021; Sri et al., 2020; Khaddam et al., 2020; Ketchen et al., 2020). Finally, the last hypothesis of the survey also tries to find out whether competitiveness has any positive effect on supply chain management or not. Our survey has indicated that the independent variable, competitiveness, has a positive 
effect on performance $(\beta=3.238$, P-value $=0.001)$. The results are consistent with findings of other studies such as Narimisa et al. (2020); Purwanto et al. (2020); Purwanto et al. (2021); Saveeva et al. (2020).

\section{Practical implications}

To increase competitiveness, hotel management must strengthen supply chain management, increasing supply chain management will encourage increased competitiveness of restaurants, therefore restaurant management must improve and maintain indicators that support supply chain management variables. Increasing competitiveness is very important in the era of the industrial revolution. 4.0 because if restaurants can't compete, they will not be able to survive. To improve restaurant performance, restaurant management must strengthen supply chain management, increasing supply chain management will encourage restaurant performance improvements, therefore restaurant management must improve and maintain indicators that support supply chain management variables. Performance improvement is very important in the digital era because if restaurant performance decreases, then it will not be able to survive.

\section{Theoretical implications}

There is a significant relationship between supply chain management and competitiveness. These results support the findings by Purwanto et al. (2021) and Ketchen et al. (2020) where they show that supply chain management has a positive and significant effect on competitiveness. This result is in line with Setiawan et al. (2021), Sri et al. (2020) and Khaddam et al. (2020), which indicate that supply chain management has a positive and significant effect on competitiveness. There is a significant relationship between Supply Chain Management and Performance. These results are in line with Purwanto et al. (2021) that supply chain management has a positive and significant effect on performance, this result is in line with Setiawan et al. (2021), Sri et al. (2020) and supported by Khaddam et al. (2020) and Ketchen et al. (2020) which state that supply chain management has a positive and significant effect on performance. There is a significant relationship between competitiveness and performance. These results support the research by Purwanto et al. (2021) that competitiveness has a positive and significant effect on performance and is in line with Setiawan et al. (2021), Sri et al. (2020), Khaddam et al. (2020) and Ketchen et al. (2020) which indicate that competitiveness has a positive and significant effect on performance.

\section{Conclusion}

Based on the results of data analysis, the results have indicated that there is a significant relationship between supply chain management and competitiveness, there is a significant relationship between supply chain management and performance and finally there is a significant relationship between competitiveness and performance. To improve the competitiveness and performance of restaurants, hotel management must strengthen supply chain management, increasing supply chain management will encourage increased competitiveness and restaurant performance, therefore restaurant management must improve and maintain indicators that support supply chain management variables. This is important in the era of the industrial revolution 4.0 because if a restaurant cannot compete, it will not be able to survive because the level of competition is very tight. For further research, it is necessary to expand respondents in other provinces and add new variables that are not discussed in this study.

\section{Research limitations}

This research was conducted in Banten Province, the results of which may not necessarily be applicable in other provinces. The sample in this study was only 290 tourists who had visited Banten province whose results could not necessarily be generalized to other tourists. Data analysis using structural equation modeling (SEM) using SmartPLS 3.0 software whose results may be different if using other statistical software. The use of the google form questionnaire is only followed by respondents who have smartphones even though many tourists do not use smartphones.

\section{References}

Affandi, A., Sarwani, A. S., Erlangga, H., Siagian, A. O., Purwanto, A., Effendy, A. A., \& Juhaeri, G. (2020). Optimization of MSMEs Empowerment in Facing Competition in the Global Market during the COVID-19 Pandemic Time. Systematic Reviews in Pharmacy, 11(11), 1506-1515.

Afum, E., Issau, K., Agyabeng-Mensah, Y., Baah, C., Dacosta, E., Essandoh, E., \& Boateng, E. A. (2021). The missing links of sustainable supply chain management and green radical product innovation between sustainable entrepreneurship orientation and sustainability performance. Journal of Engineering, Design and Technology.

Ahmed, H. (2021). A Mixed-Method Study of Investigating the Effects of Organizational Preparedness of Supply Chain Management Performance in the Food and Manufacturing Industry (Doctoral dissertation, Case Western Reserve University).

Alsmairat, M., \& Aldakhil, A. (2022). Modeling the interrelationships among environmental forces, organizational capabilities and supply chain sustainability. Uncertain Supply Chain Management, 10(1), 117-124. 
Asamoah, D., Agyei-Owusu, B., Andoh-Baidoo, F. K., \& Ayaburi, E. (2021). Inter-organizational systems use and supply chain performance: Mediating role of supply chain management capabilities. International Journal of Information Management, 58, 102195.

Borazon, E. Q., Huang, Y. C., \& Liu, J. M. (2021). Green market orientation and organizational performance in Taiwan's electric and electronic industry: the mediating role of green supply chain management capability. Journal of Business \& Industrial Marketing.

Chidir, G., Novitasari, D., Iskandar, J., Hutagalung, D., Pramono, T., Maulana, Safitri, K., Fahlevi, M., Sulistyo, A.B., \& Purwanto, A. (2021). The role of customer e-trust, customer e-service quality and customer e-satisfaction on customer eloyalty. International Journal of Data and Network Science, 6(2), 1-8

Doan, T., \& Bui, T. (2020). Nonlinear impact of supply chain finance on the performance of seafood firms: A case study from Vietnam. Uncertain Supply Chain Management, 8(2), 267-272.

Haudi, H., Rahadjengb, E. R., Santamoko, R., Putrac, R. S., Purwoko, D., Nurjannahe, D., \& Purwanto, A. (2021). The Role of E-Marketing and E-Crm on E-Loyalty of Indonesian Companies During Covid Pandemic and Digital Era. Uncertain Supply Chain Management, 10, 2022

Herden, T. T. (2020). Explaining the competitive advantage generated from Analytics with the knowledge-based view: the example of Logistics and Supply Chain Management. Business Research, 13(1), 163-214.

Jifroudi, S., Teimoury, E., \& Barzinpour, F. (2020). Designing and planning a rice supply chain: a case study for Iran farmlands. Decision Science Letters, 9(2), 163-180.

Juliana, J., Parani, R., Irene, N., Sitorus, B., Pramono, R., \& Maleachi, S. (2021). Study of Community Based Tourism in the District West Java. International Journal of Sustainable Development and Planning, 16(2), 277-285.

Muhajir, Mukaromah,H. , Fathudina , Purwanti,K.L, Ansoria,Y., Fahlevi,M., Rosmayati,S.,Tanjung, R., Budiarti ,R.H.S, Rosyadi and Purwanto,A.(2021). The role of buzz and viral marketing strategic on purchase intention and supply chain performance. Uncertain Supply Chain Management, 10(2), 1-8.

Napitupulu, J., Pramono, R., \& Saragih, E. L. L. (2021). Determinants of Tourist Attraction of the Heritage Tourism. Journal of Environmental Management \& Tourism, 12(2), 507-514.

Narimissa, O., Kangarani-Farahani, A., \& Molla-Alizadeh-Zavardehi, S. (2020). Evaluation of sustainable supply chain management performance: Indicators. Sustainable Development, 28(1), 118-131.

Prahiawan, W., Fahlevi, M., Juliana, J., Purba, J., Khamaludind, K., Syam, S., \& Lestari, S. (2022). The effect of supply chain quality perception and country of origin on Smartphones purchase intention of Indonesian consumers. Uncertain Supply Chain Management, 10(1), 277-284.

Purwanto, A., \& Juliana (2021). The effect of supplier performance and transformational supply chain leadership style onsupply chain performance in manufacturing companies. Uncertain Supply Chain Management, 10(2), 1-8

Purba, J.T., Juliana J., Budiono S., Purwanto A., Pramono R., \& Djakasaputra A. (2022). The relationship between hotel service quality and customer satisfaction: an empirical study of spa hotels in Indonesia. International Journal of Entrepreneurship, 26(1), 1-11

Purwanto, A., Asbari, M., Santoso, T. I., Sunarsi, D., \& Ilham, D. (2021). Education Research Quantitative Analysis for Little Respondents. Jurnal Studi Guru Dan Pembelajaran, 4(2), 335-350.

Pramono, R., Sondakh, L. W., Bernarto, I., Juliana, J., \& Purwanto, A. (2021). Determinants of the small and medium enterprises progress: A case study of SME entrepreneurs in Manado, Indonesia. The Journal of Asian Finance, Economics, and Business, 8(1), 881-889.

Rudyanto, R., Pramono, R., Juliana, J. (2021). Perception of Knowledge of the Risk of the COVID -19 Pandemic Regarding Touring Intentions and Tourism Travel Recommendations. Journal of Environmental Management and Tourism, (Volume XII,Summer), 4(52), 929 - 947. DOI:10.14505/jemt.v12.4(52).08

Rudyanto, R., Pramono, R., \& Purwanto, A. (2021). The influence of antecedents of supply chain integration on company performance. Bagchi, PK \& Chun HB (2005). Supply Chain Integration: a European survey. The International Journal of Logistics Management, 16(2), 275-294.

Setiawan, S., Arif, D., Mahmudah, S., Agustina, H., \& Martah, V. (2021). The effect of supply chain management on multichannel retailing and business performance. Uncertain Supply Chain Management, 9(4), 823-830.

Sri, H. (2020). Analysis supply chain management factors of lecturer's turnover phenomenon. International Journal of Supply Chain Management, 9(1), 582-591.

Khaddam, A., Irtaimeh, H., \& Bader, B. (2020). The effect of supply chain management on competitive advantage: The mediating role of information technology. Uncertain Supply Chain Management, 8(3), 547-562.

Ketchen Jr, D. J., \& Craighead, C. W. (2020). Research at the intersection of entrepreneurship, supply chain management, and strategic management: opportunities highlighted by COVID-19. Journal of Management, 46(8), 1330-1341.

Saragih, J., Tarigan, A., Silalahi, E. F., Wardati, J., \& Pratama, I. (2020). Supply Chain Operational Capability and Supply Chain Operational Performance: Does the Supply Chain Management and Supply Chain Integration Matters. International Journal of Supply Chain Management, 9(4), 1222.

Tovma, N., Shurenov, N., Bimendiyeva, L., Kozhamkulova, Z., \& Akhmetova, Z. (2020). Territorial marketing and its role in determining regional competitiveness. Evaluating supply chain management. Uncertain Supply Chain Management, 8(1), 1-16.

Utama, I. G. B. R., Laba, I. N., Junaedi, I., Krismawintari, N. P. D., Turker, S. B., \& Juliana, J. (2021). Exploring Key Indicators of Community Involvement in Ecotourism Management. UTAMA, I Gusti Bagus Rai et al. Exploring Key 
Indicators of Community Involvement in Ecotourism Management. Journal of Environmental Management and Tourism, $12,808-817$

Wang, C., Zhang, Q., \& Zhang, W. (2020). Corporate social responsibility, Green supply chain management and firm performance: The moderating role of big-data analytics capability. Research in Transportation Business \& Management, 37, 100557.

Wieland, A. (2021). Dancing the supply chain: Toward transformative supply chain management. Journal of Supply Chain Management, 57(1), 58-73.

Wijaya, O., Sulistiyani, S., Pudjowati, J., Kurniasi, N., \& Purwanto, A. (2021). The role of social media marketing, entertainment, customization, trendiness, interaction and word-of-mouth on purchase intention: An empirical study from Indonesian smartphone consumers. International Journal of Data and Network Science, 5(3), 231-238.

Yuliantoro, N., Goeltom, V., Juliana, I. B., Pramono, R., \& Purwanto, A. (2019). Repurchase intention and word of mouth factors in the millennial generation against various brands of Boba drinks during the Covid 19 pandemic. African Journal of Hospitality, Tourism and Leisure, 8(2), 1-11.

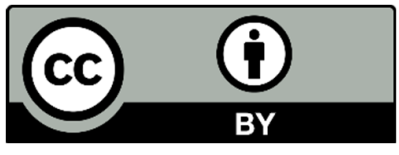

(C) 2022 by the authors; licensee Growing Science, Canada. This is an open access article distributed under the terms and conditions of the Creative Commons Attribution (CC-BY) license (http://creativecommons.org/licenses/by/4.0/). 